\title{
PENGARUH KUALITAS KERJA DAN KUALITAS PELAYANAN TERHADAP KEPUASAN MAHASISWA PROGRAM STUDI AKUNTANSI UNIVERSITAS PAMULANG
}

\author{
SRI NITTA CRISSIANA WIRYA ATMAJA \\ Prodi Akuntansi S1, Fakultas Ekonomi, Universitas Pamulang \\ *Email : nittacwa.17.10.10@gmail.com
}

\begin{abstract}
This study aims to obtain empirical evidence of the influence of work quality and service quality on the satisfaction of students of the Accounting study program at the University of Pamulang, Pamulang Banten, both partially and simultaneously.This study uses primary data in the form of a questionnaire. The sample collection technique uses purposive sampling. The research subjects were undergraduate accounting students in semester 8-14 at Pamulang University, by taking a sample of 100 respondents. Respondents' answers in the form of the questionnaire will be analyzed using multiple linear regression analysis techniques using SPSS 22.00 to be concluded.The results showed that work quality and service quality together affect student satisfaction. Partial testing concluded that work quality and service quality had a positive and significant effect on student satisfaction.
\end{abstract}

Keywords: work quality, service quality, and student satisfaction

\section{PENDAHULUAN}

Latar belakang penelitian ini adalah bahwa minat dalam bisnis jasa nirlaba semakin tinggi. Ini terbukti bahwa semakin banyaknya lembaga pendidikan dari pendidikan anak usia dini, taman kanak-kanak, SD, SMP, SMA dan universitas di sekitar kita. Dengan berkembangnya bisnis layanan nirlaba di atas, terutama universitas, sejumlah cara dilakukan, termasuk meningkatkan kualitas kerja dan kualitas layanan sebagai cara untuk menarik perhatian pelanggannya.

Menurut Goetsch dan Davis dalam Ibrahim (2008:22) mendefinisikan kualitas sebagai "suatu kondisi dinamis yang berhubungan dengan produk, jasa, manusia, proses dan lingkungan yang memenuhi atau melebihi harapan. Selanjutnya menurut Sedarmayanti (2009:252) mengemukakan 7 (tujuh) definisi kualitas yaitu:

1) Kesesuaian dengan persyaratan atau tuntutan;

2) Kecocokan untuk pemakaian;

3) Perbaikan atau penyempurnaan berkelanjutan;

4) Bebas dari kerusakan atau cacat;

5) Pemenuhan kebutuhan pelanggan awal dan setiap saat; 
6) Melakukan sesuatu secara benar awal;

7) Sesuatu yang bisa membahagiakan pelanggan.

Definisi kualitas layanan dapat diartikan sebagai upaya untuk memenuhi kebutuhan dan keinginan konsumen dan ketepatan pengiriman dalam menyeimbangkan harapan konsumen (Tjiptono, 2007).

Kepuasan adalah perasaan senang atau kecewa seseorang yang muncul setelah mebandingkan kinerja (hasil) produk yang dipikirkan terhadap kinerja (atau hasil) yang diharapkan Kotler dan Keller (2009:177). Kepuasan mencerminkan penilaian seseorang tentang kinerja produk anggapannya (atau hasil) dalam kaitannya dengan ekspektasi. Jika kinerja produk tersebut tidak memenuhi ekspektasi, pelanggan tersebut tidak puas dan kecewa. Jika kinerja produk sesuai dengan ekspektasi, pelanggan tersebut puas. Jika kinerja produk melebihi ekspektasi, pelanggan tersebut senang Kotler (2009:14). Adapun rumusan masalah dalam penelitian ini adalah:

1. Seberapa besar pengaruh kualitas kerja terhadap kepuasan mahasiwa.

2. Seberapa besar pengaruh kualitas pelayanan terhadap kepuasan mahasiwa.

3. Seberapa besar pengaruh kualitas kerja dan kualitas pelayanan terhadap kepuasan mahasiwa.

Program studi Akuntansi Universitas Pamulang, adalah satu dari belasan prodi yang ada di Universitas Pamulang dan termasuk dalam 3 besar prodi dengan jumlah murid terbanyak. Di tahun ajaran 2017-2018, program studi Akuntansi terpilih sebagai Program studi terbaik dengan sejumlah kriteria yang ditentukan oleh Lembaga Penjamin Mutu (LPM) Universitas Pamulang. Dalam kaitannya dengan hal tersebut di atas maka, program studi Akuntansi tentunya ingin berbuat lebih baik lagi bagi universitas. Sejumlah hal dilakukan diantaranya dalam peningkatan kualitas kerja pegawai dan kualitas pelayanan sehingga tujuan utamanya dapat dipenuhi, yaitu kepuasan mahasiswa

\section{TINJAUAN PUSTAKA}

Penelitian ini menggunakan data primer berupa kuisioner. Data primer adalah data yang mengacu pada informasi yang diperoleh dari tangan pertama oleh peneliti yang berkaitan dengan variabel minat untuk tujuan spesifik studi. Sumber data primer adalah responden individu, kelompok fokus, internet juga dapat menjadi sumber data primer jika koesioner disebarkan melalui internet (Uma Sekaran, 2011)

Pengertian data primer menurut Narimawati (2008:98) yaitu: "Data primer ialah data yang berasal dari sumber asli atau pertama. Data ini tidak tersedia dalam bentuk terkompilasi ataupun dalam bentuk file-file. Data ini harus dicari melalui narasumber atau dalam istilah teknisnya responden, yaitu orang yang kita jadikan objek penelitian atau orang yang kita jadikan sebagai sarana mendapatkan informasi ataupun data. 


\section{METODE PENELITIAN}

Dalam penelitian ini berarti data langsung diambil dari mahasiswa akuntansi yang sedang berada di kampus. Pengumpulan data dilakukan dengan cara mendatangi langsung kampus dan membagikan kuesioner ke mahasiswa Akuntansi S1 yang berada di lingkungan Universitas Pamulang dengan menggunakan Skala Likert. Untuk mengukur peneliti menggunakan Skala Likert berkala 5 dengan skor pada tabel 3.1 pada lampiran.

Sampel adalah bagian dari jumlah dan karakteristik yang dimiliki oleh populasi tersebut (Sugiyono, 2016: 81). Jumlah mahasiswa yang terdaftar pada periode 2017-2018 sebanyak 11.076. Namun responden dalam penelitian ini hanya berfokus pada mahasiswa semester 8-14 yang terdata pada tahun 20172018. Hal ini dikarenakan mahasiwa semester 8-14 dianggap sudah berhubungan lebih lama dengan para dosen dan karyawan sehingga diharapkan dapat memberikan penilaian yang lebih akurat.

Jumlah keseluruhan mahasiswa semester 8-14 adalah sebanyak 4.021 mahasiswa (data diambil dari staf administrasi prodi akuntansi melalui sistem sia@unpam.ac.id). Berhubung jumlah mahasiswa semester 8-14 yang terdaftar sebanyak 4.021 mahasiswa maka penulis menentukan jumlah responden menggunakan rumus slovin.

$$
n=\frac{N}{1+N e^{2}}
$$

Keterangan:

$\mathrm{n}=$ ukuran sampel

$\mathrm{N}=$ ukuran populasi

$\mathrm{e}=$ batas kesalahan

Pengambilan sampel dalam penelitian ini diambil dari nilai error variansnya atau $\mathrm{e}=10 \%$ shingga tingakt kebenaran sebesar $90 \%$, maka

$$
\mathrm{n}=\underline{4.021}=\frac{4.021}{1+4.021}=99,7
$$

Maka dibulatkan menjadi 100 responden mahasiswa semester 8-14 tahun ajaran 2017-2018.

\section{ANALISIS DATA DAN DISKUSI HASIL}

\subsection{Analisis Statistik Deskriptif}

Variabel-variabel yang digunakan dalam penelitian ini adalah kualitas kerja, kualitas pelayanan dan kepuasan mahasiswa akan diuji secara statistik deskriptif seperti yang terlihat ditabel yang ada pada lampiran.

Adapun uraian dan penjelasan dari tabel 4.1 mengenai hasil uji statistic deskriptif adalah sebagai berikut:

1. Rata-rata hitung dari variabel kualitas kerja (X1) menjelaskan bahwa jawaban minimum responden sebesar 14 dan jawaban maksimum responden sebesar 25, rata-rata total jawaban responden adalah 22,17 yang menunjukkan bahwa keseluruhan jawaban responden terhadap kepuasan mahasiswa dapat 
diperoleh nilai 2,21 (22,17/100). Nilai 2,21 mewakili seluruh jawaban responden, bahwa sebagian besar responden ragu-ragu dengan pernyataan dari kualitas kerja (dilihat dari skala likert).

2. Rata-rata hitung dari variabel kualitas pelayanan (X2) menjelaskan bahwa jawaban minimum responden sebesar 15 dan jawaban maksimum responden sebesar 25, rata-rata total jawaban responden adalah 21,83 yang menunjukkan bahwa keseluruhan jawaban responden terhadap kepuasan mahasiswa dapat diperoleh nilai 2,18 (21,83/100). Nilai 2,18 mewakili seluruh jawaban responden, bahwa sebagian besar responden ragu-ragu dengan pernyataan dari kualitas pelayanan (dilihat dari skala likert).

3. Rata-rata hitung dari variabel kepuasan mahasiswa (Y) menjelaskan bahwa jawaban minimum responden sebesar 11 dan jawaban maksimum responden sebesar 25, rata-rata total jawaban responden adalah 20,39 yang menunjukkan bahwa keseluruhan jawaban responden terhadap kepuasan mahasiswa dapat diperoleh nilai 2,03 (20,39/100). Nilai 2,03 mewakili seluruh jawaban responden, bahwa sebagian besar responden ragu-ragu dengan pernyataan dari kepuasan (dilihat dari skala likert).

\subsection{Uji Kualitas Data}

\section{Uji Validitas Data}

Uji validitas digunakan untuk mengukur sah atau valid tidaknya suatu kuesioner. Ghozali (2016:53) mengungkapkan bahwa uji validitas dilakukan dengan membandingkan nilai rhitung dengan rtabel untuk degree of freedom $(\mathrm{df})=\mathrm{n}-2$, dalam hal ini $\mathrm{n}$ adalah jumlah sampel. Pada penelitian ini sampel yang digunakan adalah 100 responden maka besarnya df adalah $100-2=98$, dengan $\mathrm{df}=98$ dan $\alpha=0,05$ sehingga didapat rtabel $=0,1966$. Berdasarkan hasil penelitian, dapat diketahui bahwa semua pernyataan dikatakan valid, karena berkorelasi secara positif dengan rhitung > rtabel, tabel hasil uji validitas terdapat pada lampiran.

\section{Uji Reliabilitas}

Ghozali (2016:47) mengatakan bahwa reliabilitas adalah alat untuk mengukur suatu kuesioner yang merupakan indikator dari variabel atau kontruk. Adapun cara yang digunakan untuk menguji reliabilitas kuesioner dalam penelitian ini adalah menggunakan rumus koefisien cronbach alpha $(\alpha)$. Suatu variabel dikatakan reliabel jika memiliki koefisien cronbach alpha $>$ taraf 0,70. Hasil pengolahan data uji reliabiltas pada aplikasi SPSS terdapat pada lampiran tabel 4.3. Berdasarkan tabel 4.3 diketahui bahwa cronbach alpha atas variabel kualitas kerja sebesar 0,807, variabel kualitas pelayanan sebesar 0,700, dan kepuasan mahasiswa sebesar 0,814 . Uji reliabilitas tersebut menunjukan hasil cronbach alpha lebih dari 0,70 sehingga dapat disimpulkan bahwa semua item pernyataan kuesioner semua variabel adalah reliabel artinya apabila pernyataan itu diajukan kembali akan memperoleh jawaban yang relatif sama dengan jawaban sebelumnya. 


\subsection{Uji Asumsi Klasik \\ 4.3.1 Uji Normalitas}

Uji normalitas ini bertujuan untuk menguji apakah variabel independen dan variabel dependen, keduanya memiliki distribusi normal atau tidak. Gambar dibawah ini adalah hasil dari uji normalitas data dengan menggunakan grafik Normal Probability Plot. Gambar Histogram dapat dilihat dilampiran pada Gambar 4.1 Normalitas Histogram 4.1.

Dari hasil pengujian pada grafik normal histogram terlihat grafik lonceng kualitas kerja dan kualitas pelayanan terhadap kepuasan mahasiswa berada ditengah dan tidak condong ke kiri maupun ke kanan. Berdasarkan hasil gambar tersebut dapat disimpulkan bahwa model regresi layak untuk dipakai karena menunjukkan pola distribusi normal dan memenuhi asumsi normalitas.

\subsubsection{Uji Multikolinearitas}

Uji multikolinearitas ini dilakukan untuk menguji apakah terdapat korelasi antara tiap variabel independen pada model regresi. Untuk melihat apakah ada atau tidaknya multikoliniaritas pada penelitian ini, dapat digunakan dengan dilihat melalui nilai Tolerance dan Variance Inflation factor (VIF). Jika nilai VIF kurang dari 10 dan tolerance lebih dari 0,10 maka tidak terjadi multikolinearitas dan sebaliknya. Tabel dapat dilihat dilampiran pada Tabel 4.4.

Dari gambar yang ada dapat dilihat bahwa masing-masing variabel bebas mempunyai nilai Variance Inflation Factor (VIF) kurang dari 10 dan tolerance lebih dari 0,10. Nilai tolerance pada variabel kualitas kerja sebesar 0,595 dengan nilai VIF sebesar 1,682. Nilai tolerance dari kualitas pelayanan sebesar 0,595 dengan nilai VIF sebesar 1,682. Oleh karena itu, dapat disimpulkan bahwa tidak terjadi multikoliniaritas antar variabel bebas dalam model regresi.

\subsubsection{Uji Heteroskedastisitas}

Ghozali (2016:134) mengatakan bahwa uji heteroskedastisitas bertujuan menguji apakah dalam model regresi terjadi ketidaksamaan variance dari residual satu pengamatan ke pengamatan yang lain. Dalam uji heterokedastisitas ini ditentukan dengan melihat grafik plot (scatterplot) seperti gambar pada lampiran pada Gambar 4.2 Heteroskedastisitas Scatterplot 4.2.

Dengan melihat hasil grafik scatterplot tersebut, dapat disimpulkan bahwa titik menyebar dibawah dan diatas angka nol (0) pada sumbu Y dan titik-titik tersebut tidak membentuk pola tertentu. Oleh karena itu, dapat disimpulkan model regresi tersebut tidak terjadi masalah heterokedastisitas.

\subsection{Uji Regresi Linear Berganda}

Uji regresi linear berganda merupakan suatu teknik yang digunakan untuk menghitung seberapa jauh hubungan antara beberapa variabel bebas (independen) dengan variabel terikat (dependen). Analisis ini untuk mengetahui pengaruh suatu variabel kualitas kerja, kualitas pelayanan, dan kepuasan mahasiswa. Persamaan regresi yang digunakan dapat dilihat pada tabel 4.5 dilampiran.

Dari tabel 4.5 diperoleh persamaan regresi sebagai berikut: 


$$
\begin{aligned}
& \mathrm{Y}=\alpha+\beta 1 \mathrm{X} 1+\beta 2 \mathrm{X} 2 \mathrm{e} \\
& \mathrm{Y}=0,067+0,573 \mathrm{X} 1+0,343 \mathrm{X} 2+\mathrm{e}
\end{aligned}
$$

Dari hasil persamaan regresi diatas menunjukkan bahwa:

1. Nilai konstanta sebesar 0,067 menunjukkan besarnya kepuasan mahasiswa di Universitas Pamulang apabila variabel kualitas kerja dan kualitas pelayanan sama dengan nol atau tidak memberikan pengaruh.

2. Nilai koefisien regresi pada variabel kualitas kerja (X1) sebesar 0,573 hal ini berarti jika variabel kualitas kerja bertambah satu satuan maka variabel kepuasan mahasiswa akan bertambah sebesar 0,573 dengan catatan variabel lain dianggap konstan.

3. Nilai koefisien regresi pada variabel kualitas pelayanan (X2) sebesar 0,343, hal ini berarti jika variabel kualitas pelayanan bertambah satu satuan maka variabel kepuasan mahasiswa akan meningkat sebesar 0,343 dengan catatan variabel lain dianggap konstan.

\subsection{Uji Koefisien Korelasi}

Uji koefisien korelasi adalah angka yang menunjukkan kuat atau lemahnya pengaruh antara dua variabel. Koefisien korelasi menunjukkan seberapa besar hubungan yang terjadi antara variabel independen $(\mathrm{X} 1, \mathrm{X} 2$,) secara bersama-sama dengan variabel dependen (Y). Nilai $\mathrm{R}$ berkisar antara 0,00 sampai dengan 1,00, jika nilai semakin mendekati 1,00, maka hubungan yang terjadi semakin kuat, sebaliknya apabila nilai semakin mendekati 0,00 maka hubungan yang terjadi lemah. Berdasarkan tabel 4.5, dapat terlihat bahwa diperoleh $\mathrm{R}$ hitung sebesar 0,700. Hal menunjukkan bahwa terjadi hubungan yang kuat antara variabel dependen dan variabel independen.

\subsection{Uji Koefisien Determinasi}

Koefisien determinasi adalah alat guna untuk mengetahui seberapa besarpengaruh variabel bebas atau independen yaitu kualitas kerja (X1), kualitas pelayanan (X2), terhadap variabel terikat atau dependen yaitu kepuasan mahasiswa (Y).

Dari tabel 4.5 dapat dilihat bahwa nilai koefisien determinasi (Adjusted R2 Square) adalah 0,490 atau 49\%. Hal ini mengidentifikasi bahwa besarnya pengaruh kepuasan mahasiswa sebesar $49 \%$ yang dipengaruhi oleh pengaruh kualitas kerja, kualitas pelayanan dan sisanya sebesar 51\% dapat dipengaruhi oleh faktor lain seperti lokasi, harga, dan lain-lain.

\subsection{Uji Statistik t}

Uji statistik t digunakan untuk mengetahui pengaruh masing-masing variabel independen terhadap variabel dependen, di mana kualitas kerja (X1), kualitas pelayanan (X2), terhadap kepuasan mahasiswa (Y), maka digunakan uji $\mathrm{t}$ menggunakan SPSS, dimana $\mathrm{df}=\mathrm{n}-\mathrm{k}$ berarti 100-2 $=98$ dengan tingkat kesalahan 5\%, maka diperoleh ttabel $=1,66055$. Hasil uji t secara parsial pada tabel 4.5 dapat dilihat bahwa variabel kualitas kerja (X1) terhadap kepuasan mahasiswa (Y) menunjukkan nilai thitung > ttabel atau 6,586>1,66055 dengan 
tingkat signifikan sebesar 0,000. Karena nilai signifikan variabel kualitas kerja (X1) lebih kecil dari 0,05 $(0,000<0,05)$, sehingga dapat disimpulkan bahwa $\mathrm{H} 1$ diterima artinya kualitas kerja berpengaruh signifikan terhadap kepuasan mahasiswa. Hasil uji t secara parsial pada tabel 4.5 dapat dilihat bahwa variabel kualitas pelayanan (X2) terhadap kepuasan mahasiswa (Y) menunjukan nilai thitung > ttabel atau 3,877 > 1,66055 dengan tingkat signifikan lebih besar dari $0,05(0,000>0,05)$, sehingga dapat disimpulkan bahwa $\mathrm{H} 2$ diterima artinya kualitas pelayanan berpengaruh signifikan terhadap kepuasan mahasiswa. Hal tersebut menunjukkan bahwa kualitas pelayanan berpengaruh positif terhadap kepuasan mahasiswa.

\subsection{Uji Statistik F}

Uji statistik F pada dasarnya menunjukkan apakah variabel independen atau bebas yang dimasukkan mempunyai pengaruh secara bersama-sama terhadap variabel dependen atau terikat. Dengan tingkat kesalahan 5\%, dimana derajat kebebasan yakni df1 $=\mathrm{k}-1$ sedangkan $\mathrm{df} 2=\mathrm{n}-\mathrm{k}$, maka df1 $=2-1=1$ sedangkan df2=100-2=98, maka diperoleh Ftabel=3,94. Hasil uji $F$ dalam Output SPSS dapat dilihat pada tabel 4.6 Anova dilampiran. Dari hasil uji F pada tabel 4.6 dapat dilihat bahwa hasil Fhitung sebesar 56,312, artinya nilai Fhitung > Ftabel (56,312 $>3,94$ ) dengan nilai signifikan sebesar 0,000. Karena nilai signifkansi lebih kecil daripada $0,05(0,000<0,05)$. Maka dapat disimpulkan bahwa H3 diterima artinya kualitas kerja (X1) dan kualitas pelayanan (X2) secara simultan berpengaruh signifikan terhadap Kepuasan Mahasiswa (Y).

\subsection{Diskusi Hasil dan Pembahasan}

\section{Pengaruh Kualitas Kerja Terhadap Kepuasan Mahasiswa.}

Hasil analisis statistik deskriptif terhadap kualiast kerja dapat diperoleh nilai 2,21 (22,17/100). Nilai 22,17 mewakili seluruh jawaban responden, bahwa sebagian besar responden ragu-ragu dengan pernyataan dari kualitas kerja. Hasil uji t secara parsial pada tabel 4.5 dapat dilihat bahwa variabel kualitas kerja (X1) terhadap kepuasan mahasiswa (Y) menunjukkan nilai thitung > ttabel atau 6,586>1,66055 dengan tingkat signifikan sebesar 0,000. Karena nilai signifikan variabel kualitas kerja (X1) lebih kecil dari 0,05 $(0,000<0,05)$, sehingga dapat disimpulkan bahwa $\mathrm{H} 1$ diterima artinya kualitas kerja berpengaruh signifikan terhadap kepuasan mahasiswa. Hal tersebut menunjukkan bahwa kualitas kerja berpengaruh positif terhadap kepuasan mahasiswa.

\section{Pengaruh Kualitas Pelayanan Terhadap Kepuasan Mahasiswa}

Hasil analisis statistik deskriptif terhadap kualitas pelayanan diperoleh nilai 2,18 (21,83/100). Nilai 2,18 mewakili seluruh jawaban responden, bahwa sebagian besar responden setuju dengan pernyataan dari kualitas pelayanan. Hasil uji t secara parsial pada tabel 4.5 dapat dilihat bahwa variabel kualitas pelayanan (X2) terhadap kepuasan mahasiswa (Y) menunjukan nilai thitung > ttabel atau 3,877>1,66055 dengan tingkat signifikan lebih besar dari 0,05 $(0,000<0,05)$, sehingga dapat disimpulkan bahwa $\mathrm{H} 2$ diterima artinya kualitas pelayanan berpengaruh signifikan terhadap kepuasan mahasiswa. Hal tersebut 
menunjukkan bahwa kualitas pelayanan berpengaruh positif terhadap kepuasan mahasiswa.

3. Pengaruh Kualitas Kerja dan Kualitas Pelayanan Terhadap Kepuasan Mahasiswa

Dari hasil uji F pada tabel 4.6 dapat dilihat bahwa hasil Fhitung sebesar 56,312 artinya nilai Fhitung $>$ Ftabel $(56,312>3,94)$ dengan nilai signifikan sebesar 0,000. Karena nilai signifkansi lebih kecil daripada $0,05(0,000<0,05)$. Maka dapat disimpulkan bahwa H3 diterima artinya Kualitas Kerja (X1) dan Kualitas Pelayanan (X2) secara simultan berpengaruh signifikan terhadap Kepuasan Mahasiswa (Y)

\section{KESIMPULAN}

Berdasarkan data yang diperoleh dalam penelitian mengenai kualitas kerja dan kualitas pelayanan terhadap kepuasan mahasiswa. Adapun responden dalam penelitian ini berjumlah 100 mahasiswa Akuntansi S1 yang sedang belajar di Universitas Pamulang, kemudian dilakukan berbagai uji statistik dan dianalisis sehingga menghasilkan kesimpulan sebagai berikut:

1. Hasil uji t secara parsial pada variabel kualitas kerja (X1) terhadap kepuasan mahasiswa $(\mathrm{Y})$ menunjukkan nilai thitung > ttabel dengan tingkat signifikansi lebih kecil dari nilai probability t, maka $\mathrm{H} 1$ diterima artinya kualitas kerja berpengaruh signifikan terhadap kepuasan mahasiswa.

2. Hasil uji t secara parsial pada variabel kualitas pelayanan (X2) terhadap kepuasan mahasiswa (Y) menunjukkan nilai thitung $>$ ttabel dengan tingkat signifikansi lebih kecil dari nilai probability t, maka $\mathrm{H} 2$ diterima artinya bahwa kualitas pelayanan terhadap kepuasan mahasiswa.

3. Dari hasil uji F diketahui bahwa Fhitung > Ftabel dengan nilai signifkansi lebih kecil dari nilai probability $\mathrm{F}$, maka $\mathrm{H} 3$ diterima artinya kualitas kerja dan kualitas pelayanan berpengaruh secara simultan dan signifikan terhadap kepuasan mahasiswa.

\section{REFERENSI}

Buchari, Alma. (2007). Manajemen Pemasaran dan Pemasaran Jasa. Bandung: CV. Alfabeta

Dharmesta, Basu Swastha. (2003). Azas-azas Marketing. Yogyakarta : Liberti

Dharmesta, Basu Swastha. 2008. Manajemen Pemasaran Modern. Yogyakarta: Liberti

Ghozali, Mochamad. (2014). Pengaruh Kualitas Pelayanan dan Harga Terhadap Kepuasan Pelnaggan Pada Expedisi di Surabaya

Hasibuan, Malayu S.P. 2003. Manajemen Sumber Daya Manusia, Jakarta: Bumi Aksara 
Kamus Besar Bahasa Indonesia, 2002:893

Kasan, Tholib. (2000). Teori dan Aplikasi Administrasi Pendidikan. Jakarta: Studia Press

Kotler, Philip \& Gary Amstrong. (2001). Prinsip-prinsip Pemasaran, Jilid II. Jakarta: Erlangga

Kotler, Amstrong. (2007). Dasar-dasar Pemasaran Edisi Bahasa Indonesia. Jakarta: PT. Prehallindo

Kotler, Phillip dan Hellen Keller. (2007). Manajemen Pemasaran Jilid 1 Alih Bahasa oleh Benyamin Molan Edisi 12. Jakarta: PT Indeks.

Kotler, Philip. (2009). Manajemen Pemasaran. Jakarta: Erlangga

Kotler, Philip. (2009). Manajemen Pemasaran, Jilid II, Edisi 11, Alih Bahasa Benyamin Molan. Jakarta: Indeks

Mulyasa, E. (2003). Manajemen Berbasis Sekolah. Bandung: PT. Remaja Rosdakarya.

Narimawati, Umi. (2008). Metodologi Penelitian Kualitatif dan Kuantitatif Teori dan Aplikasi

Rahman, Diandaris Nurhandika. (2013). Pengaruh Kualitas Pelayanan, Fasilitas, Persepsi Harga, dan Lokasi Terhadap Kepuasan Konsumen Pada Pemancingan Ngrembel Asri Gunung Pati Semarang.

Sugiyono. (2005). Statistik Untuk Penelitian Cetakan Kelima Bandung: CV. Alfabeta

Tjiptono, Fandy. (2006). Pemasaran Jasa Edisi Pertama Cetakan Kedua. Malang. Jawa Timur: Bayu Media Publishing

UU No. 20 tentang Sistem Pendidikan Nasional

PP No. 32 tahun 2013 tentang Standar Sarana dan Prasarana

http://theorymethod.blogspot.co.id/2015/12/jenis-dan-sumber-data.html

http://id.wikipedia.org/wiki/Manajemen).

http://www.pengertianpakar.com/2014/12/pengertian-dan-fungsi-pemasaran.html http://vickyindiarto.wordpress.com/2010/10/10/fungsi-fungsimanajemen/ http://id.wikipedia.org/wiki/Manajemen

https://ristiyantihp25.wordpress.com/2015/10/26/4-fungsi-utama-dalammanajemen-poac/

https://www.slideshare.net/ChristianYLokas/30-definisi-manajemen-menurutpara-ahli-2786120 